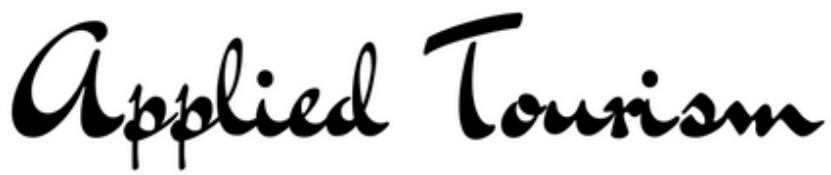 边 \\ ISSN: 2448-3524 \\ v.1 - n2 - $2016-181-203$
}

\section{UVA, VINHO E ANARQUISMO: PERSPECTIVAS E POSSIBILIDADES PARA O ENOTURISMO NA REGIÃO DE PALMEIRA - PR}

\section{GRAPE, WINE AND ANARCHISM: PROSPECTS AND POSSIBILITIES FOR TOURISM IN PALMEIRA REGION - PR}

\author{
Wilena Margraf - Bacharel em Turismo \\ Universidade Estadual de Ponta Grossa. E-mail: wika.margraf13@gmail.com \\ Mirna de Lima Medeiros - Doutora em Ciências \\ Universidade de São Paulo. E-mail: mirnadelimamedeiros@gmail.com
}

Recebido/Received: 16 junho/june 2015. Aprovação/Approval: 06 maio/may 2016

DOI: $10.14210 /$ at.v1n2.p181-203

\begin{abstract}
RESUMO: $O$ enoturismo tem se destacado nos últimos anos como modalidade turística. A união do vinho com o turismo faz parte de uma atividade que vem se desenvolvendo rapidamente e que atrai apaixonados pela bebida e curiosos. Assim surgiu o interesse de analisar as propriedades vínicas de Palmeira Paraná, suas características e possibilidades. Foi desenvolvido um estudo de caso com base em pesquisa bibliográfica, entrevistas, observação e análise documental com vistas a investigar perspectivas e possibilidades com relação ao desenvolvimento do enoturismo em Palmeira-PR. Foram realizadas doze entrevistas: dez com os produtores de vinho durante visita às suas propriedades; uma com a presidente da Associação de Turismo do município; uma com descendente do primeiro
\end{abstract}

ABSTRACT: A case study based on literature review, interviews, observation and documentary analysis was done in order to investigate possibilities and perspectives regarding the development of wine tourism in Palmeira, PR. Twelve interviews were conducted: ten with producers of wine during a visit to their properties; one with the president of the Local Tourism Association; and one with a descendant of the first producer of wine. The results show that the properties are still being prepared to receive tourists, mainly with regard to infrastructure. However, the tourist wine route is already among the Association's priorities. In addition, Palmeira can take advantage from having had the only anarchist experience in Latin America, the Cecilia Colony, where the Italians used to produce grapes and wine. 
produtor de vinho. Os resultados apontam que as propriedades ainda estão em preparo para receber turistas principalmente com relação à infraestrutura. Contudo, uma rota enoturística já está entre as prioridades da associação. Ademais, Palmeira pode se valer do diferencial de possuir a única experiência anarquista da América Latina, a Colônia Cecília, onde os italianos produziam uvas e vinho.

Palavras-chave: Enoturismo; Palmeira - PR; Colônia Cecília; Anarquismo.

\section{INTRODUÇÃO}

Ainda que a denominação enoturismo seja relativamente recente, há muito tempo se viaja pelo vinho. Degustar, conhecer a produção, conversar com o produtor e admirar paisagens e vinhedos sempre foi motivo de deslocamento. Enquanto as más condições de estradas e guerras impossibilitavam que os menos favorecidos se deslocassem grandes distâncias, as classes burguesas aproveitavam para ir além (Flores \& Flores, 2012).

As viagens em busca do vinho necessitam de cenários, paisagens, personagens, serviços de hospedagem e restauração relacionadas às vontades e expectativas dos visitantes. Ao mesmo tempo que se organiza para atender a essas demandas dos turistas, a comunidade local pode, de certo modo, fazer um resgate de suas origens e valorizar à sua prática produtiva, visto que o visitante que chega a determinado destino procura experiências, almeja degustar os produtos locais e saber como é feito o preparo do mesmo, visualizar e participar da colheita dos alimentos e levar lembranças para casa (Chiattone, 2013).

Pensando dessa forma, esse trabalho traz um estudo sobre o enoturismo na região de Palmeira - PR, mais especificamente na Colônia Santa Bárbara. Nessa localidade se instalou a única experiência anarquista da América Latina (a Colônia Cecília, liderada pelo italiano Giovanni Rossi) e atualmente ainda residem descendentes italianos, produtores de uva e vinho. Objetiva investigar perspectivas e possibilidades com relação ao desenvolvimento do enoturismo em Palmeira-PR.

A pesquisa se torna relevante na medida em que existem diversos públicos interessados em vinhos. Há as que se deslocam ao local apenas com o interesse de adquirir o produto; as que buscam nesse segmento resgatar parte de sua história e de
Keywords: wine tourism, Palmeira - PR, Cecilia colony, anarchism

\section{INTRODUCTION}

Although the denomination 'enotourism' is relatively recent, it has been long since people traveled for wine. Degusting, getting to know the production, talking to the producers admiring landscapes and vineyards have always been a reason for traveling. While the bad condition of the roads and war periods hinder the poor from traveling long distances, the bourgeoisie have continued to go on trips. (Flores \& Flores, 2012).

Travel searching for wine requires scenery, landscapes, characters, hospitality services to satisfy visitors' expectations and wishes. While it is organized to meet their demands, the local community can, in some sense, revive its origins and aggregate value to its productive practice, as the visitor reaches a particular destination demanding experiences, aiming to taste local products and learning how they are made, willing to join in the harvesting and taking home some souvenirs (Chiattone, 2013).

In this context, this work presents a study on wine tourism in the south Brazilian town of Palmeira, in Paraná, specifically, in Colonia Santa Barbara. In this locality took place the only anarchist experience in Latin America - the Cecilia Colony, led by the Italian Giovanni Rossi - which still is home to Italian descendants, grape growers and wine producers. So, this work aims to investigate prospects and possibilities regarding the development of wine tourism in Palmeira, Paraná.

This research is relevant to the extent that there are so many stakeholders interested in wines. There are those who travel to the site, interested in acquiring the product; those who seek to retrieve a piece of their history and their ancestors; those looking for a new experience, such as talking to the producer or participating the production process; or people who travel due to other motivations and end up making enotourism (also known as wine tourism), even if it is not the main reason for the trip. It is also worth mentioning the importance of wine tourism for grape and wine producers, given that this activity generates extra incomes for these families. Another point that enriches this work is the existence 
seus antepassados; as que procuram uma nova experiência, como conversar com o produtor ou participar da produção; ou ainda pessoas que viajam devido a outra motivação e acabam fazendo enoturismo, mesmo ele não sendo a razão inicial da viagem. Também é válido mencionar a importância do enoturismo para os produtores de uva e vinho, visto que essa atividade gera uma renda extra para essas famílias. Outro ponto que enriquece esse trabalho é a existência da única colônia anarquista da América Latina, que se deu em Palmeira.

O presente trabalho encontra-se estruturado em três partes principais: o primeiro traz um breve referencial teórico sobre a relação vinho e turismo e suas peculiaridades; o segundo ponto traz dados do enoturismo no Brasil; o terceiro ponto é um estudo de caso da Colônia Santa Bárbara em Palmeira, e suas ligações com a atividade enoturística. Por fim são tecidas algumas considerações finais e apresentadas as referências que embasaram o presente trabalho.

\section{O TURISMO E O VINHO}

Com base no livro The Story of Wine de Hugh Johnson (1989), é possível dizer que não se sabe com certeza o local e a época em que o vinho foi feito pela primeira vez. Há cerca de 2 milhões de anos atrás já existia a colheita de uvas. O vinho não precisou esperar para ser inventado, ele sempre esteve lá, em qualquer lugar onde uvas fossem colhidas e armazenadas em algum recipiente que pudesse reter o suco que acabava por fermentar o seu conteúdo. O vinho aparece desde as histórias bíblicas, esteve presente nas tradições de vários países no decorrer da história e hoje aparece com destaque como legado que esses povos deixaram (Johnson, 1989).

De acordo com Capello (2009), o vinho em si é apenas um líquido dentro de uma garrafa, mas pode ser transformado em uma fonte de saúde, cultura e prazer. Segundo ele, o vinho através de sua longa história e complexidade, se torna um espelho do ser humano, onde pode-se ver refletida a sua cultura. Para Capello (2009), degustar um vinho não se difere de "degustar" uma música, um quadro, um filme, uma poesia, um lugar e até uma pessoa. O vinho não possui seu valor restrito ao produto em si, conforme of the only anarchist colony in Latin America, which was established in Palmeira.

This paper has been structured into three main parts: the first presents a brief theoretical framework on wine and tourism relationship and their characteristics; the second point looks into Brazil's wine tourism data; the third part is a case study of the Colony Santa Barbara in Palmeira, and its links to wine activities. Finally, some conclusions and references that supported this work are presented.

\section{TOURISM AND WINE}

Based on the book "The Story of Wine" by Hugh Johnson (1989), one can say that it is not known with certainty the place and time when wine was first made. About two million years ago there was already a grape harvest. The wine did not have to wait to be invented, he was always there, wherever grapes were harvested and stored in a container that could hold the juice that would eventually ferment. Wine is mentioned in biblical stories, has been present in the traditions of many countries throughout history and today features prominently as a legacy that those people have left (Johnson, 1989).

According to Capello (2009), the wine itself is just a liquid in a bottle, but it can turn into a source of health, culture, and pleasure. The author says that the wine, through its long history and complexity, becomes a mirror of the human being, in which their culture is reflected. For Capello (2009), tasting a wine does not differ from "tasting" a song, a painting, a film, a poem, a place and even a person. Wine does not have its value limited to the product itself, as stated Ferreira (2010), focusing on its attraction potential linked to traditional agricultural activities and to the entertaining and educational aspects of tourism, it can be transformed into a gastronomic product capable of attracting trips and visits.

The enotour refers to tourism activity in which wine is the key motivator. The main purposes of a wine tourist are wine tasting, visiting the vineyards, wineries or even participate in the harvest and production (Tonini, 2005). According to Bordini and Ruschmann (2009) wine tourism is relatively new. Although wine and tourism have been linked for some time, this relationship has only been acknowledged by governments, researchers and the economic sectors recently. 
comenta Ferreira (2010), tendo em vista o seu potencial de atração ligado às atividades agrícolas tradicionais e ao aspecto lúdico e educacional que se pode se afirmar através do turismo, pode ser transformado num produto gastronômico motivador de viagens e visitas.

O enoturismo, se caracteriza pela atividade turística onde o vinho é a principal motivação. O motivo principal do deslocamento do enoturista concentra-se na degustação de vinhos e nas visitações de locais produtores de uva e vinho, podendo conhecer e até participar da elaboração dos mesmos (Tonini, 2005). Segundo Bordini e Ruschmann (2009) a organização do enoturismo é algo relativamente novo. Apesar do vinho e o turismo estarem ligados há tempos, essa relação só começou a ser reconhecida pelos governos, pesquisadores e pelos setores dessa atividade econômica, recentemente.

De acordo com Falcão (2009) existem três tipos de enoturistas: os consumidores ocasionais, os consumidores interessados e os dedicados. Para os consumidores ocasionais o enoturismo é apenas um componente da oferta do destino, o interesse pelo vinho é superficial e valorizam-se os aspectos complementares do local. Para os consumidores interessados o enoturismo é um componente muito relevante no destino; a decisão de viajar para tal local dá ênfase ao turismo de vinhos, podendo ser essa a primeira razão do deslocamento; e procuram saber sobre a bebida mesmo sem uma base técnica para isso. Já os consumidores dedicados viajam em busca do vinho com grande expectativa, planejam muito bem a viagem; estudam anteriormente o destino e procuram conhecer aspectos técnicos sobre o vinho. $\mathrm{O}$ autor ressalta o que cada consumidor procura numa visita:

- Consumidor ocasional: visitas leves, com duração de até uma hora e meia; provas de vinhos comerciais; acolhimento informativo (não técnico).

- Consumidor interessado: visitas completas e privadas; provas de vinhos de gama média; acolhimento personalizado; cursos e outras atividades ligadas ao vinho.

- Consumidor dedicado: visitas técnicas guiadas por enólogos e produtores; provas de vinhos especiais; desejam conhecer particularidades, questões ligadas ao envelhecimento da bebida e tendências.
According to Falcão (2009) there are three types of enotourists: occasional consumers, concerned consumers, and dedicated consumers. For occasional consumers, wine tourism is only a component of the attractions of destination, their interest in wine is superficial and the value is set on the complementary aspects of the site. For interested consumers the opportunity to have wine tourism is a very important component of destination; the decision to travel to such a place is influenced by wine tourism, this may be the first reason to travel, also seeking to understand about drinking (even without a technical basis for that). Dedicated consumers travel in search of wine with great anticipation, plan the trip well; study the destination beforehand and seek to know the technical aspects of wine. The author points out what each consumer is looking for in a visit:

- Occasional Consumer: Light visits, lasting up to an hour and a half; commercial wine tastings; informative host (non-technical).

- Interested consumer: complete and private visits; mid-ranged wine tasting; personalized welcome; workshops and other activities related to wine.

- Dedicated Consumer: Technical guided tours by winemakers and enologists; degustation of special wines; want to know particular issues related to aging and drink trends.

Falcão (2009) also points out the services and features demanded by enotourists in general, regardless of their type. Namely: elements that refer to wine culture (museums, art and architecture, monuments); appreciation of the natural landscape; differentiated means of transport and information signs.

Before the visit, as aforementioned, the grape and wine may be the motivation for the trip (Ferreira, 2010). During the visit, there are several activities which can be developed within wine tourism, such as the grape harvest; participation in wine production; vineyard walks; visits to the winery and cellars.

Also, after the visit the wine may be relevant as it can be consumed as a souvenir of the trip or as a gift for someone who has not been on site (Horodyski et al., 2014). In this case, it may possibly incite curiosity and motivate a new trip (of the person who have received the gift). 
Falcão (2009) também aponta serviços e características demandados pelos enoturistas de maneira geral, independentemente do seu tipo. A saber: elementos que remetem à cultura vínica (museus, arte e arquitetura, monumentos); valorização da paisagem natural; meios de transportes diferenciados e sinalização.

Antes da visita, como mencionado anteriormente, a uva e o vinho podem ser elementos motivadores do deslocamento (Ferreira, 2010). Durante a visitação, podese destacar diversas atividades passiveis de serem desenvolvidas dentro do enoturismo, tais como: colheita da uva; participação na produção vínica; passeio por entre as videiras; visitação à vinícola e adegas. Também pósvisita a produção vitícola pode ser relevante ao consumidor sendo consumida na forma de souvenirs servindo como lembrança pessoal da visitação de algum destino e/ou como presente para alguma pessoa que não esteve no local (Horodyski et al, 2014). Nesse segundo modo pode eventualmente incitar a curiosidade e motivar um novo deslocamento (da pessoa que recebeu o presente).

Produtos alimentícios e bebidas que são adquiridas em determinado destino podem ser inseridos na categoria souvenir gastronômico. É desejável, contudo, que o souvenir gastronômico possua: identidade diferenciadora, identificação de origem, embalagem adequada e transporte facilitado. Deve ser capaz de materializar as experiências vivenciadas, compartilhar as lembranças e motivar outras pessoas a novas viagens (Horodyski et al, 2014).

Por fim, cabe destacar que, nos dias de hoje, segundo Ferreira (2010), a produção vinícola já não deve ser encarada como uma mera atividade agrícola. Ao integrar tal produção com atividades turísticas, disponibilizadas pelas propriedades e/ou adegas, pode-se diversificar os meios de gerar riqueza e, ao mesmo tempo, potencializar as sinergias entre a produção e a própria comercialização do vinho.

\section{ENOTURISMO NO BRASIL}

Segundo Flores \& Flores (2012) atualmente no Brasil há 80 mil hectares de vinhedos, contando com as variedades de mesa e as viníferas. As mais famosas e importantes regiões, indo de norte a sul do país, são:
Food and beverage that are acquired at a destination can enter the category of food souvenir. It is desirable, however, that this souvenir has a distinctive identity, the identification of the source, appropriate packaging and easy transport. It should be able to materialize the experiences, share memories and motivate others to new trips (Horodyski et al., 2014).

Finally, it is worth noting that today, according to Ferreira (2010), wine production should no longer be seen as just farming. By integrating such production with tourist activities offered by the properties and/ or cellars, one can diversify the means of generating wealth and at the same time, enhance the synergies between the production and marketing of the wine itself.

\section{WINE TOURISM IN BRAZIL}

According to Flores and Flores (2012) currently in Brazil there are 80,000 hectares of vineyards, with the varieties of table and wine grapes. The most famous and important regions, from north to south, are: São Francisco, in Petrolina zone (PE); São Joaquim, in Santa Catarina; and in Rio Grande do Sul (region which produces $90 \%$ of Brazil's wine) is the Valley of the Vineyards and the Campanha Gaucho. It is in this State that the greatest wine tradition of the country can be observed. This has begun with the arrival of Italian immigrants. In this region, it is planted more than nine thousand hectares of vineyards, passing the towns of Bento Gonçalves, Garibaldi and Monte Belo.

The lands of southern Brazil are known for their gaucho features, the style of Argentine and Uruguayan pampas. Varieties that are hardly to find in Europe, such as Lorraine, Isabella, Niagara, Ruby, Bordô, Terci (Ives) and Burgundy are found in smallholder farms. It was with these grape varieties that the Italian immigrants arrived from the Veneto, Lombardy or Friulli have started developing the first wines (Flores \& Flores, 2012).

In the study entitled "Diagnosis of the Brazilian enotour", Maria Amelia Duarte Flores and Andiara Flores (2012) make an overview of the country's wine tourism interest regions. Besides the already mentioned, it also appears São Roque, Circuito das Frutas, and São Carlos, in the state of São Paulo; Andradas in Minas Gerais; Pedra Azul region and Santa Teresa in Espirito Santo; Vale do Rio São 
São Francisco, na zona de Petrolina (PE); São Joaquim em Santa Catarina; e, no Rio Grande do Sul (região onde se produz 90\% do vinho brasileiro) está o Vale dos Vinhedos e a Campanha Gaúcha. É na terra gaúcha que se percebe a maior tradição vinícola do país. Tradição essa, iniciada com a chegada dos imigrantes italianos. Nessa região são plantados mais de nove mil hectares de vinhedos, passando pelos municípios de Bento Gonçalves, Monte Belo e Garibaldi.

As terras do Sul do Brasil são conhecidas por suas características gaúchas, ao estilo dos pampas argentinos e uruguaios. Ali são encontradas plantações de pequenos proprietários, com variedades que dificilmente se encontra na Europa, como a Lorena, a Isabel, Niágara, Rubi, Bordô, Tercy e a Borgonha. Foi com essas qualidades de uva que os imigrantes italianos chegados do Vêneto, de Friulli ou Lombardia começaram a elaborar os primeiros vinhos (Flores \& Flores, 2012).

No estudo intitulado "Diagnóstico do enoturismo brasileiro", Maria Amélia Duarte Flores e Andiara Flores (2012) fazem um apanhado das regiões de interesse enoturístico do país. Além das já citadas, aparecem outras, como: São Roque, Circuito das Frutas e São Carlos no estado de São Paulo; Andradas em Minas Gerais; Região da Pedra Azul e Santa Teresa no Espírito Santo; Vale do Rio São Francisco pegando parte dos estados de Pernambuco e Bahia; e, Marialva, Bituruna, Colombo, São José dos Pinhais, Santa Felicidade e Campo Largo no estado do Paraná.

Para que a união turismo e vinho alcance seus objetivos é necessário um olhar especial ao consumidor, tanto real quanto potencial, e suas necessidades e anseios. No referido diagnóstico elaborado para o Instituto Brasileiro do Vinho (Flores \& Flores, 2012) houve também uma análise das oportunidades e ameaças dentro da atividade. Em meio às principais oportunidades é necessário destacar o crescimento da classe $C$ no Brasil, classe essa que costuma adquirir produtos que mostram status, que não economiza, viaja em períodos curtos e começa a se interessar pelo mundo dos vinhos. Também é válido destacar a força da "geração $Y$ ", pessoas nascidas entre 1978 e início dos anos 80, fiéis adeptos dos videogames, computadores e internet. São os jovens que querem tudo urgente, detestam monotonia, consomem vinho e adoram viajar.
Francisco in the states of Pernambuco and Bahia; and Marialva, Bituruna, Colombo, São José dos Pinhais, Santa Felicidade, and Campo Largo, all in the state of Paraná.

So that the link between tourism and wine attains its goals, it is necessary a special look at the needs and wants of actual or potential customers. In an assessment made for the Brazilian Wine Institute (Flores \& Flores, 2012), there is also an analysis of the opportunities and threats within the activity. Among the main opportunities, it is important to highlight the growth of the social class $C$ in Brazil. This class often buys products that show status, which does not economize, travel for short periods, and begins to be interested in the world of wine. It is also worth highlighting the strength of "Millennials" (Generation Y), people born between 1978 and the early 80s, faithful fans of video games, computers and internet. They are young people who want everything fast, hate monotony, consume wine and love to travel.

Also according to Flores and Flores (2012), the experience economy has grown as an important aspect of the enotour activity. According to the Ministry of Tourism (2010), the experience tour is a revolutionary form of tourism, that offers visitors the opportunity to go beyond the observation, and participate as an actor on that location and in that history, leading to strong and unforgettable memories, also, it is important to note that the tourist is one of the biggest promoters of the visited site. The wine tourism and some of its activities can be conceived as tourism of experience.

It was also found that most of the public who attends enotour itineraries in Brazil are families with children. This fact must be seen as an opportunity for this market, since activities for the children can be planned within the tour so that parents may enjoy it better (Flores \& Flores, 2012). The study also mentions other market opportunities such as: the relationship between wine and health or drink and business tourism; the connection of wine to romanticism; and the curiosity of the wine tourist.

As writes Valduga (2007) both consumers and non-consumers are curious about wine and its origins and that is an advantage to wine tourist. Lifestyle, status, landscapes, people involved in the production and gastronomy are some of the wine-related elements that contribute to its specific image and set it apart 
Ainda segundo Flores \& Flores (2012), destaca-se a economia da experiência como um ponto importante dentro da atividade enoturística. De acordo com o Ministério do Turismo (2010), o tour de experiência é uma forma revolucionária de oferta turística, que oferece ao visitante a possibilidade de ir além da observação, e participar como personagem daquele local e daquela história, levando lembranças mais fortes e inesquecíveis, é importante destacar que esse turista é um dos maiores divulgadores do destino. $O$ enoturismo e algumas de suas atividades podem se encaixar como turismo de experiência.

Foi também encontrado que a maior parte do público que frequenta roteiros enoturísticos no Brasil são famílias com crianças. Esse fato pode ser visto como oportunidade para 0 mercado enoturístico, visto que se planejadas atividades para os filhos dentro do próprio roteiro, os pais aproveitam mais o passeio e prestam atenção nas visitas (Flores \& Flores, 2012). Parte desse estudo também menciona como oportunidades de mercado: a relação do vinho com a saúde, o vínculo da bebida com o turismo de negócios, o romantismo envolto ao vinho e a curiosidade do turista de vinhos.

Como escreve Valduga (2007) o vinho possui a vantagem de despertar o interesse nos consumidores e não-consumidores em conhecer a origem do produto, isso faz com que o enoturismo se fortaleça. Por possuir uma sequência de fatores que o envolvem, como: tradição; estilo de vida; status; paisagens; pessoas que participam da elaboração e gastronomia; o vinho se difere de produtos eletrônicos, alimentos em geral ou produtos de limpeza, e acaba por motivar as pessoas a conhecerem as regiões produtoras.

O enoturismo também possui fraquezas, ou pontos fracos que precisam de um olhar especial e um melhor planejamento. No caso específico do Brasil, apontam-se as seguintes questões: desconhecimento da população sobre os destinos enoturísticos existentes no país; o turismo não é visto com profissionalismo pelo setor; pouco investimento em marketing e propaganda por parte das rotas e roteiros vínicos; não investimento em arquitetura e paisagismo; propriedades muito similares dentro de uma mesma rota, o que resulta em uma visita maçante (Flores \& Flores, 2012).

\section{ASPECTOS METODOLÓGICOS}

A pesquisa utilizou uma abordagem qualitativa que, segundo Sampieri, Collado \& from other consumption products. Ultimately, all of this motivates people to know the producing regions.

The wine tourism also has a few weaknesses though, which need a specific look and better planning. Regarding Brazil's case, the following points are highlighted: lack of knowledge of the population about the existing enotourist destinations in the country; tourism is not envisaged professionally by the sector; little investment in marketing and advertising about the routes and wine itineraries; no investment in architecture and landscaping; very similar properties within the same route, which sometimes turns in a boring visit (Flores \& Flores, 2012).

\section{METHODOLOGICAL ASPECTS}

The research used a qualitative approach which, according to Sampieri, Collado and Lucio (2013), is useful when it is necessary to understand the participants' perspective on the events that involve them. This type of approach is recommended when the studying topic was little explored, or when there is no research done regarding some particular social group. This research is of an exploratory nature, aiming to provide an overview of a certain fact (Gil, 2008).

The case study was chosen to develop the proposal because the aim is to obtain a broad and detailed knowledge of the subject by means of in-depth study (Gil, 2008). The data collection tools used were: literature review; document analysis; observation; and unstructured interviews, since it allowed openended questions and the inclusion of new questions during the research development.

Given the variety of perspectives on the history of Cecilia Colony and wine production in the city, twelve research subjects were approached. (Appendix A - List of respondents, Source: research data, 2015).

With the producers, the interview took place on the visit to the studied properties, mostly in the town of Santa Barbara. These properties were selected based on the production capability and products known in the city. The analyzed productions range from 400 to 20,000 bottles of wine a year and from 500 to 5,000 grape juice bottles production per year.

The data analysis was performed through content analysis, which used to describe 
Lucio (2013), é útil quando se faz necessário compreender a perspectiva dos participantes sobre os fenômenos que os cercam. É recomendável esse tipo de enfoque quando o tema do estudo foi pouco explorado, ou que não tenha sido feita pesquisa sobre ele em algum grupo social específico. $O$ trabalho possui justamente esse caráter exploratório, que tem como objetivo proporcionar uma visão geral sobre determinado fato (Gil, 2008).

Optou-se pelo estudo de caso como meio para o desenvolvimento da proposta, pois propõe-se a realização do profundo estudo de um objeto de forma a permitir o seu conhecimento amplo e detalhado (Gil, 2008). As ferramentas de coleta de dados utilizadas foram: pesquisa bibliográfica; observação, análise documental e entrevistas não-estruturadas, pela facilidade em fazer perguntas abertas e incluir questões no decorrer da pesquisa.

Tendo em vista a riqueza de perspectivas com relação a história da Colônia Cecília e a produção de vinhos na cidade foram abordados 12sujeitos de pesquisa. (Apêndice A - Lista de entrevistados, fonte: dados da pesquisa, 2015).

No caso dos produtores, a entrevista ocorreu em visita às propriedades, as quais foram analisadas, sendo a maioria na localidade de Santa Bárbara. Essas propriedades foram selecionadas a partir do tamanho da produção e dos produtos já conhecidos na cidade. As produções analisadas vão de 400 a 20 mil garrafas de vinho/ano e de 500 a 5 mil garrafas de suco de uva/ano.

A forma de análise usada nesta pesquisa foi a análise de dados, a qual é usada para descrever e interpretar conteúdos de materiais verbais e não-verbais (Moraes, 1999). Também foi utilizado o método da triangulação de dados, que consiste em olhar para o mesmo fenômeno a partir de várias fontes de dados, ou seja, informações vindas de vários ângulos (Azevedo et al, 2013). A triangulação pode combinar fontes de dados e métodos qualitativos e quantitativos, neste trabalho optou-se pela combinação de entrevistas, observações, documentos, pesquisas bibliográficas e notas de campo.

\section{ESTUDO DE CASO}

O Município de Palmeira e sua relação com o vinho and interpret verbal and nonverbal material (Moraes, 1999). The method of triangulation was also used, it consists of looking at the same phenomenon from various data sources, that is, information coming from various angles (Azevedo et al., 2013). Triangulation can combine data sources and qualitative and quantitative methods; this study opted for the combination of interviews, observations, documents, literature review, and field notes.

\section{CASE STUDY}

\section{The Municipality of Palmeira and its relationship with wine}

Palmeira is a municipality in the south Brazilian state of Paraná, with an area of $1,457.262$ square kilometers and a population of 32,123 inhabitants (IBGE, 2010). It is located on the second plateau of Paraná and is bordered by the cities of Lapa, Ponta Grossa, São João do Triunfo, Teixeira Soares, Porto Amazonas, and Campo Largo. It is $80 \mathrm{~km}$ from the state capital, Curitiba; $181 \mathrm{~km}$ of the Port of Paranaguá and $103 \mathrm{~km}$ from Afonso Pena Airport, in São José dos Pinhais. As for access, it is crossed by two federal railways and one state highway.

Palmeira's relationship with wine goes back to its first years, according to Neusa Sklasky, there are evidences that her great-grandfather Giuseppe Capraro was the first wine producer in the city of Palmeira. He would have arrived in the city in 1885. According to Bach (2011), on the land that he had acquired, Giuseppe started a plantation of Isabella grape variety. The wine he made became famous under the label of Barbera wine. On that label, the production was identified as José Capraro's, name that Giuseppe adopted in Brazilian territory.

He married and had eleven children, among them, Hugo Capraro (Neusa's grandfather) and Silvio Capraro have continued the production of wines. The Brazilian Agricultural Institute had awarded Giuseppe for his wine quality. Nilton Wendler, Neusa's brother and also José's great-grandson, is today one of the city's winemakers. It was in the city of Palmeira that, from 1890 to 1894 , an anarchist colony (Cecilia Colony) settled, formed by Italians. This experience is described in more detail above. 
O município de Palmeira, localizado no interior do Paraná, conta com uma área territorial de $1.457,262 \mathrm{~km}^{2}$, e uma população de 32.123 habitantes (IBGE, 2010). Está localizado no segundo planalto paranaense e faz divisa com os municípios da Lapa, Ponta Grossa, São João do Triunfo, Teixeira Soares, Porto Amazonas e Campo Largo. Está a 80 km da capital do estado, Curitiba; 181 km do Porto de Paranaguá e a $103 \mathrm{~km}$ do Aeroporto Afonso Pena, em São José dos Pinhais. Quanto ao acesso, é cortado por duas rodovias federais e uma rodovia estadual.

A relação de Palmeira com o vinho aparece já nos primeiros anos da cidade, segundo Neusa Sklasky, há indícios de que seu bisavô Giuseppe Capraro foi o primeiro produtor de vinho na cidade de Palmeira. Ele teria chegado na cidade em 1885. De acordo com Bach (2011), nas terras que adquiriu, Giuseppe iniciou uma plantação de videiras do tipo Isabel. O vinho que ele fabricava ficou famoso sob o rótulo de vinho Barbera. Nesse rótulo a produção era identificada como de José Capraro, nome que Giuseppe passou a usar em terras brasileiras.

Ele se casou e teve 11 filhos, dentre eles Hugo Capraro (Avô de Neusa) e Silvio Capraro, os quais continuaram a produção de vinhos. Giuseppe chegou a ser premiado pelo Instituto Agrícola Brasileiro pela qualidade do seu vinho. Nilton Wendler, irmão de Neusa e também bisneto de José, é hoje um dos produtores de vinhos do município. Foi na cidade de Palmeira que se instalou nos anos de 1890 a 1894 uma Colônia anarquista (Colônia Cecília), formada por italianos, essa experiência merece uma descrição mais profunda, que se encontra na próxima sessão.

Colônia Cecília: a experiência anarquista em Palmeira

Segundo Mayer (2013) no final do século XIX o governo imperial motivava a vinda de imigrantes europeus para o sul do Brasil, com o objetivo de povoar as terras que precisavam ser desbravadas. Nas terras de Palmeira (PR) já se encontravam os portugueses, os colonizadores; escravos africanos; os alemães do Volga; e os recém-chegados poloneses. A Colônia da Santa Bárbara, localizada na zona rural do município de Palmeira, era um desses locais destinados a colonização, e no ano de 1890 passou a abrigar a experiência anarquista.

\section{CECILIA COLONY: THE ANARCHIST EXPERIENCE IN PALMEIRA}

According to Mayer (2013) in the late nineteenth century, the imperial government motivated the arrival of European immigrants to the south of Brazil, in order to populate and clear the lands. In Palmeira (PR) territory, there were already the Portuguese, the colonizers; the African slaves; the Volga Germans; and Polish newcomers.

The Colony of Santa Barbara, located in rural area of the municipality of Palmeira, was one of those places for colonization, and in 1890 it housed the anarchist experience.

Giovanni Rossi, born in Pisa, Italy, in 1856, was a mix of philosopher, journalist, poet, musician, scientist, agronomist by vocation, and veterinarian by profession. Convinced of his anarchist premises, he devised an experimental colony in South America and ended up opting for Brazil motivated by the Brazilian publicity to the European labor market. In February 1890, Rossi and five other pioneers left from the port of Genoa bound for Rio de Janeiro and arrived there on March 18. On the 26 of the same month, the group embarked to the state of Rio Grande do Sul, but the trip malaise affected two members of the group, which advanced their landing on March 30, in Paranaguá. The mild and healthy climate of Paraná made them stay (Mayer, 2013).

They continued their journey by train to the city of Curitiba, where they received from the Land and Colonization Authority a plot of land of approximately 200 hectares in Palmeira. In early April, Rossi and his followers arrive at the municipality, and with the help of an Italian doctor who had lived there, settled in the place that was reserved.

On the land in which they have settled, today Santa Barbara Colony, they built a shed that served as an auditory, warehouse and bedroom, this place was also called "House of love and brotherhood." For couples, there were private huts. They took advantage of the area available for building roads, mills, vines and to plant corn and other grain.

At the French Colony, at the outskirts of Palmeira for those who follow the road to Santa Barbara, Rossi met a family originating from Avignon that impressed him enough to characterize its members as the most civilized of the region. Madame Louise, at the time of 
Giovanni Rossi, nascido em Pisa, Itália, em 1856, era um misto de filósofo, cientista, agrônomo por vocação e veterinário por profissão, jornalista, poeta, músico. Convicto das premissas anarquistas, idealizou uma colônia experimental na América do Sul e acabou optando pelo Brasil motivado pela propaganda brasileira ao mercado de trabalho europeu. Em fevereiro de 1890 partiram Rossi e outros cinco pioneiros do porto de Gênova com destino ao Rio de Janeiro e ali chegaram no dia 18 de março. No dia 26 do mesmo mês o grupo embarcou novamente com o objetivo de chegar ao Rio Grande do Sul, mas o malestar da viagem afetou dois integrantes do grupo, desembarcando então, no dia 30 de março, em Paranaguá. A existência do clima ameno e saudável do Paraná os fizeram ficar (Mayer, 2013).

Seguiram viagem de trem até a cidade de Curitiba, onde em contato com a Inspetoria de Terras e Colonização, receberam um terreno de aproximadamente 200 hectares no município de Palmeira. Nos primeiros dias de abril Rossi e seus seguidores chegam ao município, e, com a ajuda de um médico italiano que ali já vivia, se estabeleceram no local que os foi reservado.

No terreno em que se instalaram, hoje Colônia Santa Bárbara, construíram um barracão que servia de auditório, armazém e dormitório, esse local era também chamado de "Casa do amor e da fraternidade". Para os casais existiam barracos individuais. Aproveitaram a área disponível para construir estradas, moinhos, parreiras e para plantar milho e cereais.

Na Colônia Francesa, saída de Palmeira para quem segue a Santa Bárbara, Rossi encontrou uma família oriunda de Avignon, que o impressionou a ponto de caracterizar seus membros como os mais civilizados da região. Madame Louise, quando da instalação do núcleo anarquista, era casada com o italiano Giuseppe Capraro. O casal manteve relações de amizade com os pioneiros socialistas e doou as primeiras mudas de videira (uva Isabel), possibilitando a formação do parreiral da recém-criada Cecília. (Mello Neto, 1996, p.140)

De acordo com Bach (2011), Giuseppe Capraro e Giovanni Rossi se visitavam com frequência e trocavam experiências, a união da teoria com a prática ocasionaram bons resultados. O número de mudas de videiras foi se multiplicando e o parreiral da Cecília the settling of the anarchist group, was married to the Italian Giuseppe Capraro. The couple maintained friendly relations with the socialist pioneers and have donated the first vine cuttings (Isabella grape) for the vineyard of the newly created Cecilia. (Mello, 1996, p.140)

According to Bach (2011), Giuseppe Capraro and Giovanni Rossi visited each other frequently and exchanged experiences, this union of theory and practice led to good results. The number of vines seedlings multiplied and Cecilia's vineyard grew, anarchists bet on viticulture and wine production as a source of income that could in future be the basis of the Colony economy. In Appendix B a vineyard from that time is shown. (Appendix B - Cecilia Colony's vineyard, source: Bach, 2011).

In 1891 new members began to arrive. According to Rossi's own writings, between 1891 and 1892 the colony was home to about 250 people. Its last year was also the peak of the experience; the good relations with merchants and the city authorities, granted credit for the settlers.

Giovanni Rossi sought to create a colony so that his ideas could be confirmed, he wanted to show a communal life, without any form of power, be it state power, religious or familial.

As a result of the short period of existence of Cecilia, the anarchist settlers did not have time to produce wine on a commercial scale, as they have planned. However, the descendants who remained in lands of Cecilia (now Santa Barbara) as the Mezzadri, the Artusi, and Agottani, took with them the seedlings and the techniques they learned from Rossi and Capraro. Wine production has become, for these families, a major source of income. The wines of Santa Barbara, an artisanal production, have become known regionally and is one of the legacies left from Cecilia Colony (Bach, 2011).

The Cecilia Colony existed from 1890 to 1894, but the end of the experiment was not due to any specific fact, but to a sum of issues which led to its extinction. Among the possible causes there are: the difficult relationship with neighbors; the life of misery; maladaptation of colony members to rural work; the existence of the family as a social unit, (in times of crisis, families began hiding food to give their children, going against the anarchist ideals); and, at last, Rossi's tiredness which led to his abandonment of the colony after he had proven his thesis: communal life would only 
aumentava, os anarquistas apostavam na vinicultura e viam na produção de vinhos uma fonte de renda que poderia ser futuramente a base da economia da Colônia. No apêndice $B$ expõe-se um parreiral daquela época (Apêndice B - Parreiral da Colônia Cecília, fonte: Bach, 2011).

Em 1891 novos integrantes começaram a chegar. De acordo com escritos do próprio Rossi, entre 1891 e 1892 a colônia abrigava cerca de 250 pessoas. Foi nesse último ano o auge da experiência, onde através das boas relações com os comerciantes e autoridades da cidade abriram-se créditos para os colonos.

Giovanni Rossi buscou criar uma colônia para que suas ideias pudessem ser comprovadas, ele queria mostrar a realização de uma vida comunitária, sem nenhuma forma de poder, tanto na questão estatal, religiosa e familiar.

Em consequência do curto período de tempo da existência da Cecília, os colonos anarquistas não tiveram tempo para produzir o vinho em escala comercial da maneira que planejavam. Entretanto, os descendentes que permaneceram nas terras cecilianas (hoje Santa Bárbara) como os Mezzadri, os Artusi e os Agottani, levaram consigo as mudas e as técnicas que aprenderam com Rossi e Capraro. A produção de vinho passou a ser, para essas famílias, uma das principais fontes de renda. Os vinhos de Santa Bárbara, produzidos artesanalmente, se tornaram conhecidos regionalmente e é um dos legados que a Colônia Cecília deixou (Bach, 2011).

A Colônia Cecília existiu de 1890 a 1894, o fim da experiência não foi definido por um fato específico, mas por uma soma de pontos que determinaram sua extinção, entre as causas estão: as dificuldades de relacionamento com vizinhos; o grau de miséria que viviam na colônia; não adaptação aos trabalhos rurais por parte dos integrantes da colônia; a existência da família como unidade social, nos momentos de crise, as famílias começaram a esconder alimentos para dar aos seus filhos, indo contra os ideais anarquistas; e por fim, o cansaço de Rossi, que abandonou a colônia ao ver comprovada sua tese: a vida comunitária só seria possível se destruído o casamento monogâmico, e com ele a paternidade (Mayer, 2013).

Enoturismo em Palmeira-PR: Possibilidades e Perspectivas

O turismo de vinhos tem se destacado nas últimas décadas dentre as modalidades be possible if the monogamous marriage and paternity were destroyed (Mayer, 2013).

\section{WINE TOURISM IN PALMEIRA, PR: POSSIBILITIES AND PROSPECTS}

Wine tourism has stood out in recent decades among the modalities of tourism. Apart from the fact that wine and tourism have great impact on the economy, together or separated, they carry great symbolic significance and share common characteristics. In this sense, wine and tourism can play a great role in contemporary society: the pursuit of pleasure, the desire to escape and to share, as Mitchell writes (2004, cited by Zanini \& Rocha 2010, p.71). Several Brazilian cities and regions have wine tourism potential, as pointed out by Flores and Flores (2012) in the survey carried out by IBRAVIN, to differentiate at the various options. It is up to each local to highlight their particular features, in order to become the chosen destination for consumers-tourists.

Ferreira (2010) points out that it is natural to take advantage of the link between wine and food, and other forms of regional cultural heritage, as a way to create wealth for both activities. This, says the author, is likely to happen primarily through wine tourism. The anarchist experience in the city of Palmeira, unique in Latin America, allied to its winemaking tradition can be exploited as distinctive features with high potential in terms of tourism.

Wine tourism, according to the literature review, is characterized by the act of traveling motivated by the wine. A wine with a distinctive story combined with a former anarchist colony can trigger that motivation. It is, however, pointed out that tourists need beforehand information to make the decision to visit a place (Kotler \& Keller, 2012). Currently, no information was found, regarding the city or private properties, highlighting the possibility of visits.

In the case of Palmeira, production associated with the grape can benefit producers, who thus have diversified their production and increased family income. According to the city's agriculture secretary, in natura grape yields $\mathrm{R} \$ 14,000$ (gross) per hectare, adding up the products (juices, wines, preserves) it reaches $\mathrm{R} \$ 25,000$ net. Isabella grape and "Bordô" grape, used to produce wine in Palmeira, are not vinifera 
de atividade turística, além do fato de movimentar a economia de vários países, o vinho e o turismo, juntos ou isolados, carregam grande significado simbólico e apresentam características em comum. Nesse sentido, o vinho e o turismo podem representar na sociedade contemporânea: a busca por prazer, o desejo de fuga e de compartilhar, como escreve Mitchell (2004, citado por Zanini \& Rocha 2010, p.71). Várias cidades e regiões brasileiras apresentam potencial enoturístico, conforme apontado por Flores \& Flores (2012) no diagnóstico realizado pelo IBRAVIN, para se diferenciar ante as diversas opções cabe a cada local destacar seus atributos particulares para que se torne o destino escolhido pelos consumidores-turistas que almeja.

Ferreira (2010) aponta que é natural que ocorra o aproveitamento da ligação do vinho à gastronomia e a outras formas do patrimônio cultural regional, como forma de criar riqueza para ambas as atividades. Isso, destaca o autor, é passível de ser feito sobretudo através do enoturismo. Assim, diante do diferencial da única experiência anarquista da América Latina na cidade de Palmeira, e de sua tradição na produção de uvas, vinhos e derivados, é possível vislumbrar no município um potencial, ainda pouco explorado na atividade turística.

O enoturismo, conforme visto na revisão bibliográfica, se caracteriza pelo deslocamento onde o motivo central é o vinho. Um vinho com história diferenciada aliada à de uma colônia anarquista pode corroborar para que essa motivação exista. Cabe, entretanto, destacar que o turista precisa ter informações prévias para tomar a decisão de visitar (Kotler \& Keller, 2012). No momento não foram encontrados materiais, nem da cidade e nem das propriedades particulares, que destaque a possibilidade das visitas.

No caso do município de Palmeira, a produção associada à uva pode beneficiar os produtores, que dessa forma diversificaram sua produção e aumentaram a renda familiar. Segundo o secretário de agricultura da cidade, a uva in natura rende $\mathrm{R} \$ 14$ mil reais brutos por hectare, já com a produção dos derivados (sucos, vinhos, geleias) chega a dar $\mathrm{R} \$ 25 \mathrm{mil}$ líquidos. A uva Isabel e a uva Bordo, utilizadas para a fabricação de vinhos em Palmeira, são variedades não viníferas, são elas que dão origem aos sucos de uva e aos "populares" vinhos de mesa. Entretanto, essas variedades menos nobres, aos poucos, vêm ganhando a varieties, grape juices and "popular" table wines are made of them. However, these less noble varieties have gradually been gaining the producers' attention. According to Barelli (2015) the naturally produced wine is gaining ground and, depending on the work performed, it can position itself among premium wines. The author also mentions that "there are small producers who find it difficult to be organized as a company, but still make interesting wines" (Barelli, 2015, p.38). It is also worth mentioning that the table wine is the best-selling wine in Brazil, i.e., this product has space in the market and good consumer acceptance, and there is even a law regulating the marketing of table wine produced on small farms.

According to the Ministry of Agriculture (2014) the Law 12,959 / 2014, enacted in 2014, which regulates the marketing and production of colonial or artisanal wine, that is, the one that is produced by rural family entrepreneur or family farmer. This standard requires that the wine is made with at least $70 \%$ of grapes produced in the family farm, and that maximum production is of 20,000 liters per year. The law also defines that production of the wine, standardization and bottling are made exclusively in the rural farmer's property. Regarding the sale, it is established that it must be made directly to the final consumer at the place where it was produced, in family farming markets, or establishment maintained by associations or cooperatives of farmers. This law can strengthen the production of wine in small properties, as well as encourage the consumer to go to the property to purchase the product directly from those who have produced it.

In the specific case of Palmeira, diversification of rural business through tourism could also be an alternative to expand the income of producers, however, the survey has shown that enotourism in the region is not developed yet and that the properties are still preparing to receive tourists. Some grape and wine producers have shown interest in tourism and are being trained to better serve visitors, SENAR (National Rural Education Service) in partnership with EMATER (Entity for Technical Assistance and Rural Extension) of Palmeira offered the course "Qualifying the Rural Producer", which is targeted to these small farmers and their families. The course assists those producers, so that they learn how to develop and better manage the small farm. 
atenção de produtores. De acordo com Barelli (2015) o vinho produzido de forma natural está ganhando espaço e, dependendo do trabalho realizado, pode posicionar-se entre os vinhos premium. Menciona ainda que "Existem produtores pequenos que tem dificuldade de ser organizar como empresa, mas que fazem vinhos interessantes" (BARELLI, 2015, p.38). Também cabe ressaltar que o vinho de mesa é o vinho mais vendido em nosso país, ou seja, esse produto possui espaço no mercado e boa aceitação dos consumidores, e existe até uma lei que regulamenta a comercialização do vinho de mesa produzido em pequenas propriedades.

Segundo o Ministério da Agricultura (2014) foi sancionada no ano de 2014 a Lei 12.959/2014, a qual disciplina a comercialização e produção do vinho colonial ou artesanal, ou seja, aquele que é produzido pelo empreendedor familiar rural ou agricultor familiar. Essa norma determina que o vinho seja elaborado com pelo menos $70 \%$ de uvas produzidas na propriedade rural familiar e que essa produção seja máxima de 20 mil litros anuais. A lei também prevê que a elaboração do vinho, a padronização e o envasilhamento sejam feitos exclusivamente no imóvel rural do agricultor. Em relação a comercialização da bebida, se estabelece que a venda seja feita diretamente ao consumidor final, na sede da propriedade onde foi produzida, em feiras de agricultura familiar ou em estabelecimento mantido por associação ou cooperativa de produtores rurais. Essa lei pode fortalecer a produção do vinho nas pequenas propriedades, assim como incentivar que o consumidor se dirija até a propriedade para adquirir o produto diretamente com quem o produziu.

No caso específico de Palmeira a diversificação do negócio rural por meio da pluriatividade inserindo o turismo também poderia ser uma alternativa para ampliação da renda dos produtores, entretanto, através da pesquisa realizada, observa-se que o turismo de vinhos na região ainda não é forte, e que as propriedades ainda se preparam para receber turistas. Alguns produtores de uva e vinho mostraram interesse na atividade turística e estão se capacitando para melhor atender esses visitantes, o SENAR (Serviço Nacional de Aprendizagem Rural) em parceria com a EMATER (Empresa de assistência técnica e extensão rural) do município de Palmeira ofereceram o curso "Qualificando o Produtor Rural", o qual é voltado para esses pequenos produtores rurais e sua família. O curso dá assistência a esses produtores para que os
Although there are challenges for the wine tourism consolidation as a tourist modality in this region, there is interest from the Municipality and the Tourism Association in enhancing this activity including in a wine route the heritage of Cecilia Colony, and thus increasing the flow of people visiting the site.

In an interview with the director of the Historic Museum of Palmeira and president of the Tourism Association of the Municipality, Vera Lúcia de Oliveira Mayer, the feasibility of a route of grape and wine in town, and aspects regarding Cecilia Colony were some of the issues tackled. According to her, Cecilia and anarchism attract many people to the city, from students of history to curious tourists from all over the country and from different locations in the world. To remember the great historical and cultural importance of this experience lived by the anarchists in Palmeira, a Memorial of the Colony was built encompassing a house, a plaza square and totems that depict the story of it (Appendix C: photos of the Memorial of Cecilia Colony, source: research data, 2015).

In one of these totems some of the main families that inhabited the colony according to anarchist principles, together with Giovanni Rossi, are listed. Some of these (the Mezzadri, the Artusi and the Agottani) took with them the seedlings and the techniques they have learned from Rossi and Capraro, and his descendants, and to the present day, produce grapes and wine in the region, which can be visited.

According to Vera, a wine route was already being pondered and three departments are working to enhance the region: the Department of Industry, Trade and Tourism; Department of Environment and Department of Agriculture. For 2016 is already on the agenda to improve the tourist signs on the roads that lead to Santa Barbara, where are located the winemaking properties and the Cecilia Colony's Memorial, inaugurated in April 2015. It is expected that by 2019 the wine route is already opened. A portal will be built and some attractions belonging to this route will be revived. Also according to the president of the Association, the wines produced in Santa Barbara will go on sale in tourist information centers of Palmeira and in Witmarsum Colony (colony also belonging to Palmeira, PR, founded by German Mennonites) and also in the Anarchist memorial.

Interviews with the winemakers, during the visits to the properties, revealed that most 
mesmos aprendam a desenvolver e melhor administrar a pequena propriedade rural.

Ainda que existam desafios para que o enoturismo se consolide como modalidade turística nessa região, existe o interesse por parte da Prefeitura e da Associação de Turismo em potencializar essa atividade vinculando dentro de uma rota de vinhos a questão da Colônia Cecília, e assim aumentando o fluxo de pessoas que visitam o local.

Em entrevista realizada com a diretora do Museu Histórico de Palmeira e presidente da Associação de Turismo do Município, Vera Lúcia de Oliveira Mayer, foram feitas perguntas relacionadas à viabilidade de uma rota da uva e do vinho na cidade, e também questionados alguns pontos sobre a Colônia Cecília. Segundo ela, a Cecília e o anarquismo atraem muitas pessoas para o município, desde estudantes de história a turistas curiosos, do país inteiro e também de localidades diversas do mundo. Pela grande importância histórica e cultural dessa experiência vivenciada pelos anarquistas em terras palmeirenses, foi construído um Memorial da Colônia com casa, praça e totens que contam a história da mesma (Apêndice C: Fotos do Memorial da Colônia Cecília, Fonte: dados da pesquisa, 2015).

Em um desses totens se elenca algumas das principais famílias que habitaram à colônia segundo os preceitos anarquistas junto a Giovanni Rossi. Algumas dessas (os Mezzadri, os Artusi e os Agottani) levaram consigo as mudas e as técnicas que aprenderam com Rossi e Capraro e seus descendentes até os dias atuais produzem uva e vinho na região sendo passíveis de serem visitados.

De acordo com Vera, uma rota do vinho já vinha sendo pensada e três secretarias estão trabalhando para potencializar a região: a Secretaria de Indústria, Comércio e Turismo; Secretaria de Meio Ambiente e Secretaria de Agricultura. Para 2016 já está em pauta a melhoria da sinalização turística das estradas que levam à Santa Bárbara, local onde estão situadas as propriedades vínicas e o Memorial Colônia Cecília, inaugurado em abril de 2015. A previsão é que até 2019 a rota do vinho esteja funcionando, será feito um portal e revitalizados alguns atrativos que pertencerão a essa rota. Ainda de acordo com a presidente da associação, os vinhos produzidos em Santa Bárbara serão colocados à venda nos postos de informações turísticas de Palmeira e da colônia de Witmarsum (colônia também pertencente ao município de Palmeira - PR, fundada por alemães menonitas) e também no próprio memorial anarquista. have no facilities for receiving tourists and not everyone is interested in developing activities related to tourism. Appendix D describes that reality (Appendix D - Results of surveys of producers. Source: research data, 2015).

All producers have space for selling products and serve at any time the arriving tourists, that service to visitors is not done in a professional manner, there are no guided tours but visits accompanied by conversation. In one case, the producer said that he is not interested in tourism development, because he already has regular clients who buy almost the whole of his annual production in a onetime sale.

There are several activities that can be done within a destination/enotourism property. In the appendices some of them are exposed, highlighting the ones that exist in properties visited (Appendix E - Activities of wine properties in Palmeira. Source: Research data, 2015).

Through the survey it is noted that there are few existing activities in the properties, and that those that exist are made in an unprofessional fashion. Also, products sold do not meet all the requirements to be considered a good food souvenir. According to Horodyski et al. (2014) they should have identification, packaging, identity and easy transport. Products from Palmeira only had identity (product linked to anarchism) and identification of origin. Thus, a work with respect to communication, labeling and packaging could be interesting for producers interested in attending tourists.

In addition to the sale of products in the producer's properties, for two years there has been in Palmeira, the Grape Fair where for a week grape and its products are marketed, such as juices, wines, preserves, jellies and jams. According to Nilton Wendler, Secretary of Agriculture and also a grape grower, both in 2014 and in 2015 about five tons of grapes have been sold during the fair.

These data show that the city has potential in tourism and wine, and if exploited, it can attract more people to the location. The distinctive feature of the city, is the fact that it gave shelter to the single anarchist colony in Latin America. These settlers produced grape and wine, giving historical and cultural context for the product sold today in the city, as some producers are direct descendants of the anarchists. This originality and characteristics can be attractive to tourists, once the traveler 
Em entrevistas realizadas com os produtores de vinhos durante visita às propriedades, percebeu-se que a maioria ainda não possui infraestrutura para recepção de turistas e nem todos possuem interesse em desenvolver atividades relacionadas ao turismo. No apêndice $D$, apresenta-se a descrição da realidade encontrada (Apêndice D - Resultado das pesquisas feitas com os produtores, Fonte: dados da pesquisa, 2015).

Todos os produtores possuem espaço para venda de produtos e atendem turistas que chegam a qualquer hora, esse atendimento aos visitantes não é feito de forma profissional, não possui visita guiada e sim uma visitação feita na base da conversa. Em um dos casos em que o produtor menciona não se interessar pelo desenvolvimento turístico, ele comenta que não possui interesse pois já possui clientela fixa, que compra quase toda sua produção do ano de uma só vez.

Várias são as atividades que podem ser realizadas dentro de um destino/propriedade enoturística. Nos apêndices são expostas algumas delas destacando as que se mostram presentes nas propriedades visitadas (Apêndice E - Atividades das propriedades vitivinícolas de Palmeira, Fonte: Dados da pesquisa, 2015).

Através da pesquisa realizada nota-se que são poucas as atividades existentes nas propriedades, e que, as que existem são feitas de forma mais coloquial. Também se percebeu que, os produtos vendidos não seguem todos os requisitos para serem considerados um bom souvenir gastronômico. Segundo Horodyski et al (2014) eles necessitariam ter identificação, embalagem, identidade e transporte facilitado. No caso dos produtos palmeirenses identificou-se apenas identidade (produto ligado ao anarquismo) e identificação de origem. Assim, um trabalho com relação à comunicação, rotulagem e embalagem poderia ser interessante aos produtores interessados em atender aos turistas.

Além da venda dos produtos nas propriedades dos produtores, há dois anos é feita em Palmeira, a Feira da Uva, onde são comercializados durante uma semana tanto a uva quanto seus derivados, como sucos, vinhos, geleias e compotas. Segundo Nilton Wendler, Secretário de Agricultura e também produtor de uva, tanto em 2014 como em 2015 foram vendidas aproximadamente cinco toneladas de uva durante a feira. "consumes places" (its culture, its resources, the environment, the landscape, among other subjective possibilities) and are looking more and more for meaningful and emotional experiences arising from the particular characteristics of a place (Tonini \& Lavandoski, 2011). It must be reaffirmed that this is the distinctive feature of the wine produced in Palmeira, since the wine table from the colony is already an existing product.

Given the described scenario it is possible to observe that the activity needs better planning and a great incentive to consolidate it in the region. Following there are some considerations regarding this work, and suggested some future research to overcome the limitations of the present study.

\section{FINAL CONSIDERATIONS}

This study aimed to investigate prospects and possibilities regarding the development of wine tourism in Palmeira, Paraná. According to the literature review and interviews it was revealed that there is interest from public agencies and some of the local producers to make wine tourism happen, however better planning and encouragement are required, so that enotourism develops in an orderly manner.

Although the research I sof an exploratory nature, its notes contribute to the dissemination of this tourist modality in the Palmeira region, both for residents and for potential tourists and visitors. Some activities which can be developed in the destination were listed, so it may encourage local producers to analyze the possibilities of their properties to meet potential visitors' wishes.

During the work it was noticed some limitations of research, which hampered the further discussion of some points, the main ones were: poor signing of wine properties; the fact that enotourism is not completely consolidated on the site; and the difficulty to visit all properties in the region as a result of the short time available. Therefore, here are some suggestions for future work, such as conducting research on potential source markets; listing strengths and weaknesses of wine tourism in the location, and the planning and execution of a grape and wine route in this region.

\section{REFERENCES}

AGRICULTURA, M. Lei do vinho colonial. 2014. 
Esses dados mostram que a cidade possui potencial nas áreas de turismo e vinho, e que se potencializados, podem atrair mais pessoas ao local. Nota-se o diferencial do município, pelo fato de ter dado abrigo a única colônia anarquista da América Latina. Esses colonos produziram uva e vinho, dando contexto histórico e cultural para o produto vendido hoje na cidade, visto que alguns dos produtores são descendentes diretos dos seguidores das premissas anarquistas. Essa originalidade e características próprias podem ser atrativos aos turistas posto que o viajante "consome lugares" (sua cultura, seus recursos, o ambiente, a paisagem, entre outras possibilidades subjetivas) e busca cada vez mais experiências às quais possa atribuir significado e emoções decorrentes das características e vivências particulares ao lugar (Tonini \& Lavandoski, 2011). Cabe reafirmar que esse é o diferencial do vinho produzido em Palmeira, visto que o vinho colonial de mesa é um produto já existente.

Diante do cenário supraexposto é possível observar que a atividade precisa de um melhor planejamento e maior incentivo para que consolide de fato nessa região. À continuidade são tecidas algumas considerações com relação ao presente trabalho e sugeridas algumas pesquisas futuras ante às limitações enfrentadas no decorrer do processo.

\section{CONSIDERAÇÕES FINAIS}

O presente trabalho teve como objetivo investigar perspectivas e possibilidades com relação ao desenvolvimento do enoturismo em Palmeira-PR. De acordo com as pesquisas bibliográficas e entrevistas realizadas foi possível perceber que há interesse por parte de órgãos públicos e por alguns dos produtores locais em fazer o turismo de vinhos acontecer, porém precisa-se de um melhor planejamento e incentivo por parte dos mesmos para que a modalidade em questão aconteça de forma ordenada.

Ainda que a pesquisa se caracterize como exploratória, seus apontamentos contribuem com a divulgação desse modal turístico na região de Palmeira tanto para os seus próprios moradores quanto à potenciais turistas e visitantes. Algumas atividades passiveis de serem desenvolvidas no destino foram listadas o que pode incentivar, de forma certa forma, os produtores locais a realizar uma autoanalise quanto às suas propriedades e/
Disponível em: <http://www.planalto.gov. br/ccivil_03/_Ato2011-2014/2014/Lei/ L12959.htm>

Azevedo, C. E. F. et al. (2013). A Estratégia de Triangulação: Objetivos, Possibilidades, Limitações e Proximidades com o Pragmatismo.In: IV Encontro de Ensino e Pesquisa em Administração e Contabilidade. Brasília. Anais. Available in: http://www.anpad.org.br/diversos/ trabalhos/EnEPQ/enepq_2013/2013_ EnEPQ5.pdf

Bach, A. M. (2011). Colônia Cecília. Ponta Grossa: Estúdio Texto.

Barelli, S. (2015). As nobres uvas de segunda classe. Revista Menu. No 195. Maio.

Bordini, C. V.; Ruschmann, D. V. de M. (2009). Enoturismo In: Segmentação do Mercado Turístico:estudos, produtos e perspectivas. Barueri, São Paulo: Manole, p. $241-253$.

Capello, M. (2009). Raio-X da atual produção vinícola brasileira. Revista Anuário Vinho do Brasil. Rio de Janeiro, p. 28-31. Edição especial.

Chiattone, V. M. (2013). Enoturismo: atrativo e ferramenta para o desenvolvimento sustentável de regiões. Available in: http://www.ucs.br/etc/revistas/index. $\mathrm{php} / \mathrm{rosadosventos/article/view/1735/}$ pdf_205

Falcão, J. M. (2009). Tendências do enoturismo. Available in: http://www. turismodeportugal.pt/Portugu\%C3\%AAs/ AreasAtividade/desenvolvimenteinovacao/ ReuniaoTecnicaEnoturismo/ ObjectivosePrograma/Documents/ VINITUR.pdf

Ferreira, F. R. R. (2010). Enoturismo: Produto Estratégico para atractividade dos destinos turísticos. 126f. Dissertação (Mestrado em Gestão Estratégica de Destinos) - Escola Superior de Hotelaria e Turismo do Estoril, Estoril (Portugal).

Flores, M. A. D.; Flores, A. (2012). Diagnóstico do enoturismo brasileiro: um mercado de oportunidades. Brasília, DF: SEBRAE: Bento Gonçalves, RS: IBRAVIN. Available in: <http://www.ibravin.org.br/public/ upload/downloads/1377631662.pdf>.

Gil, A. C. (2008). Métodos e técnicas de pesquisa social. 6a ed. - São Paulo: Atlas.

Horodyski, G. S. et al. Souvenirs Gastronômicos como Lembranças de Viagem : um estudo de caso em Curitiba - Brasil. (2014).Via@ - Revista Internacional e interdisciplinar de turismo, n. 2, p. 1-16.

IBGE. População de Palmeira. 2010. Disponível em: http://cidades.ibge.gov.br/xtras/ perfil. php?codmun $=411770$ 
ou possibilidades para atender aos visitantes em potencial.

No decorrer do trabalho percebeuse algumas limitações de pesquisa, o que dificultaram a discussão mais aprofundada de alguns pontos, as principais foram: má sinalização das propriedades vínicas; o fato do enoturismo não estar completamente consolidado no local; e a dificuldade de visitação à todas as propriedades da região em consequência do curto período de tempo disponível. Diante disso, apontamse sugestões para trabalhos futuros, como: realização de pesquisas de demanda em potenciais núcleos emissores; elencar pontos fracos e fortes do turismo de vinhos no local e o planejamento e execução de uma rota da uva e do vinho nessa região.

\section{REFERÊNCIAS BIBLIOGRÁFICAS}

Agricultura, M. Lei do vinho colonial. 2014. Disponível em: <http://www.planalto.gov. br/ccivil_03/_Ato2011-2014/2014/Lei/ L12959.htm>

Azevedo, C. E. F. et al. (2013). A Estratégia de Triangulação: Objetivos, Possibilidades, Limitações e Proximidades com o Pragmatismo. In: IV Encontro de Ensino e Pesquisa em Administração e Contabilidade. Brasília. Anais. Disponível em: <http://www.anpad.org.br/ diversos/trabalhos/EnEPQ/enepq_2013/2013_ EnEPQ5.pdf>.

Bach, A. M. (2011). Colônia Cecília. Ponta Grossa: Estúdio Texto.

Barelli, S. (2015). As nobres uvas de segunda classe. Revista Menu. № 195. Maio.

Bordini, C. V.; Ruschmann, D. V. de M. (2009). Enoturismo In: Segmentação do Mercado Turístico: estudos, produtos e perspectivas. Barueri, São Paulo: Manole, p. $241-253$.

Capello, M. (2009). Raio-X da atual produção vinícola brasileira. Revista Anuário Vinho do Brasil. Rio de Janeiro, p. 28-31. Edição especial.

Chiattone, V. M. (2013). Enoturismo: atrativo e ferramenta para o desenvolvimento sustentável de regiões. Disponível em: <http://www.ucs.br/ etc/revistas/index.php/rosadosventos/article/ view/1735/pdf_205>

Falcão, J. M. (2009). Tendências do enoturismo. Disponivel em: <http://www. turismodeportugal.pt/Portugu\%C3\%AAs/ AreasAtividade/desenvolvimentoeinovacao/ ReuniaoTecnicaEnoturismo/ObjectivosePrograma/ Documents/VINITUR.pdf>.

Ferreira, F. R. R. (2010). Enoturismo: Produto Estratégico para atractividade dos destinos turísticos. $126 f$. Dissertação (Mestrado em Gestão Estratégica de Destinos) - Escola Superior de Hotelaria e Turismo do
Johnson, H. A história do vinho. (1989). Available in: < http://www.cca.ufscar. $\mathrm{br} /$ vico/Vinho/A\%20HISTORIA \% 20 DO\%20VINHO.pdf $>$.

Kotler, P.; Keller, K. L. (2012). Administração de Marketing.14 Ed. São Paulo: Pearson Education do Brasil.

LEI No 12.959, DE 19 DE MARÇO DE 2014. Disponível em: http://www.planalto.gov. br/ccivil_03/_Ato2011-2014/2014/Lei/ L12959.htm

Mayer, V. L. de O. (2013). Colônia Cecília:uma experiência anarquista em Palmeira $P R$. 1890 - 1894. Instituto Histórico e Geográfico de Palmeira. Available in: < http://issuu.com/ihgpalmeira/ docs/artigo_colonia_cecilia_-_uma_ experi?e $=8856026 \% 2 F 7112172>$.

Mello Neto, C. (1996). O anarquismo experimental de Giovanni Rossi. Ponta Grossa. Editora UEPG. 296p.

Moraes, R. (1999). Análise de conteúdo. Revista Educação, Porto Alegre, v. 22, n. 37, p. 7-32. Available in: <http:// cliente.argo.com.br/ mgos/analise_de_ conteudo_moraes.html>.

Sampieri, R. H.; Collado, C. F.; Lucio, M. P. B. (2013). Metodologia de pesquisa. 5a Ed. Porto Alegre: Penso.

Tonini, H. (2005). Enoturismo: o vinho como produto turístico. Revista turismo em análise. Disponivel em <https:// www.turismoemanalise.org.br/ turismoemanalise/article/view/428/235>

Tonini, H.; Lavandoski, J. (2011). Enoturismo: experiências e sensações no Vale dos Vinhedos (RS). Revista Turismo em Análise. Available in: <http://www. revistas.usp.br/rta/article/view/14239>.

Turismo, M. (2010). Manual Tour da experiência 2010: conceituação. Available in: <http://www.tourdaexperiencia.com. br/arquivos/manual_conceituacao.pdf $>$.

TURISMO, M. Manual Tour da experiência 2010: conceituação. Disponível em:<http://www.tourdaexperiencia.com. $\mathrm{br} /$ arquivos/manual_conceituacao.pdf $>$.

Valduga, V. (2007). O processo de desenvolvimento do enoturismo no vale dos Vinhedos. Caxias do Sul. Available in: <https://repositorio.ucs.br/jspui/ bitstream/11338/193/1/Dissertacao\%20 Vander\%20Valduga.pdf $>$.

Zanini, T.V.; Rocha, J. M. (2010). O enoturismo no Brasil: um estudo comparativo entre as regiões vinícolas do Vale dos Vinhedos $(R S)$ e do Vale do São Francisco (BA/PE). Revista Turismo em análise. Available in: <http://www.revistas.usp.br/rta/ article/view/14206/16024>. 
Estoril, Estoril (Portugal).

Flores, M. A. D.; Flores, A. (2012). Diagnóstico do enoturismo brasileiro: um mercado de oportunidades. Brasília, DF: SEBRAE: Bento Gonçalves, RS: IBRAVIN. Disponível em: <http://www.ibravin.org.br/public/ upload/downloads/1377631662.pdf>.

Gil, A. C. (2008). Métodos e técnicas de pesquisa social. $6^{a}$ ed. - São Paulo: Atlas.

Horodyski, G. S. et al. Souvenirs Gastronômicos como Lembranças de Viagem : um estudo de caso em Curitiba - Brasil. (2014).Via@ - Revista Internacional e interdisciplinar de turismo, n. 2, p. 1-16.

IBGE. População de Palmeira. 2010. Disponível

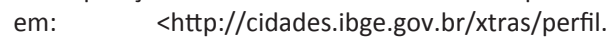
php?codmun $=411770>$

Johnson, H. A história do vinho. (1989). Disponível em: $<\quad$ http://www.cca.ufscar.br/ vico/Vinho/A\%20 HISTORIA\%20DO\%2OVINHO.pdf >.

Kotler, P.; Keller, K. L. (2012). Administração de Marketing.14 Ed. São Paulo: Pearson Education do Brasil.

LEI № 12.959, DE 19 DE MARÇO DE 2014. Disponível em: <_http://www.planalto.gov.br/ccivil_03/_Ato20112014/2014/Lei/L12959.htm>.

Mayer, V. L. de O. (2013). Colônia Cecília: uma experiência anarquista em Palmeira -PR. 1890 - 1894.Instituto Histórico e Geográfico de Palmeira. Disponível em: < http://issuu.com/ihgpalmeira/docs/artigo_colonia_ cecilia_-_uma_experi?e $=8856026 \% 2$ F7112172>.

Mello Neto, C. (1996). O anarquismo experimental de Giovanni Rossi. Ponta Grossa. Editora UEPG. 296p.

Moraes, R. (1999). Análise de conteúdo. Revista Educação, Porto Alegre, v. 22, n. 37, p. 7-32. Disponível em: $<$ http://cliente.argo.com.br/ mgos/analise_de conteudo_moraes.html>.

Sampieri, R. H.; Collado, C. F.; Lucio, M. P. B. (2013). Metodologia de pesquisa. 5 a Ed. Porto Alegre: Penso.

Tonini, H. (2005). Enoturismo: o vinho como produto turístico. Revista turismo em análise. Disponível em <https://www.turismoemanalise.org.br/ turismoemanalise/article/view/428/235>

Tonini, H.; Lavandoski, J. (2011). Enoturismo: experiências e sensações no Vale dos Vinhedos (RS). Revista Turismo em Análise. Disponível em: <http://www. revistas.usp.br/rta/article/view/14239>.

Turismo, M. (2010). Manual Tour da experiência 2010: conceituação. Disponivel em:<http://www. tourdaexperiencia.com.br/arquivos/manual_ conceituacao.pdf $>$.

Valduga, V. (2007). O processo de desenvolvimento do enoturismo no Vale dos Vinhedos. Caxias do Sul. Disponível em:<https://repositorio.ucs.br/jspui/ bitstream/11338/193/1/Dissertacao\%20Vander\%20 Valduga.pdf $>$.

Zanini, T.V.; Rocha, J. M. (2010). O enoturismo no Brasil: um estudo comparativo entre as regiões vinícolas do Vale dos Vinhedos (RS) e do Vale do São Francisco $(B A / P E)$.Revista Turismo em análise. Disponível em:<http://www.revistas.usp.br/rta/article/ view/14206/16024>. 


\section{APÊNDICES / APPENDICES}

\begin{tabular}{|l|c|}
\hline Representantes do poder público & Vera Lúcia de Oliveira Mayer \\
\hline Descendente do primeiro produtor & Neusa Sklasky \\
\hline & Altair Ruppel \\
& Atílio Mezzadri \\
Produtores & Augusto Gogola \\
& Bento Fragoso Robes \\
& Evaldo Agottani \\
& José Antônio Costa \\
& José Antônio Gabre \\
& Juvêncio Covalski \\
& Nilton Wendler \\
& Reginaldo Riffert \\
\hline
\end{tabular}

Lista de entrevistados. Fonte: Dados da pesquisa, 2015.

\begin{tabular}{|l|c|}
\hline Government representant & Vera Lúcia de Oliveira Mayer \\
\hline First producer descendant & Neusa Sklasky \\
\hline & Altair Ruppel \\
& Atílio Mezzadri \\
& Augusto Gogola \\
& Bento Fragoso Robes \\
& Evaldo Agottani \\
& José Antônio Costa \\
& José Antônio Gabre \\
& Juvêncio Covalski \\
& Nilton Wendler \\
& Reginaldo Riffert \\
\hline
\end{tabular}

Interviewees' list.. Source: Research data, 2015.

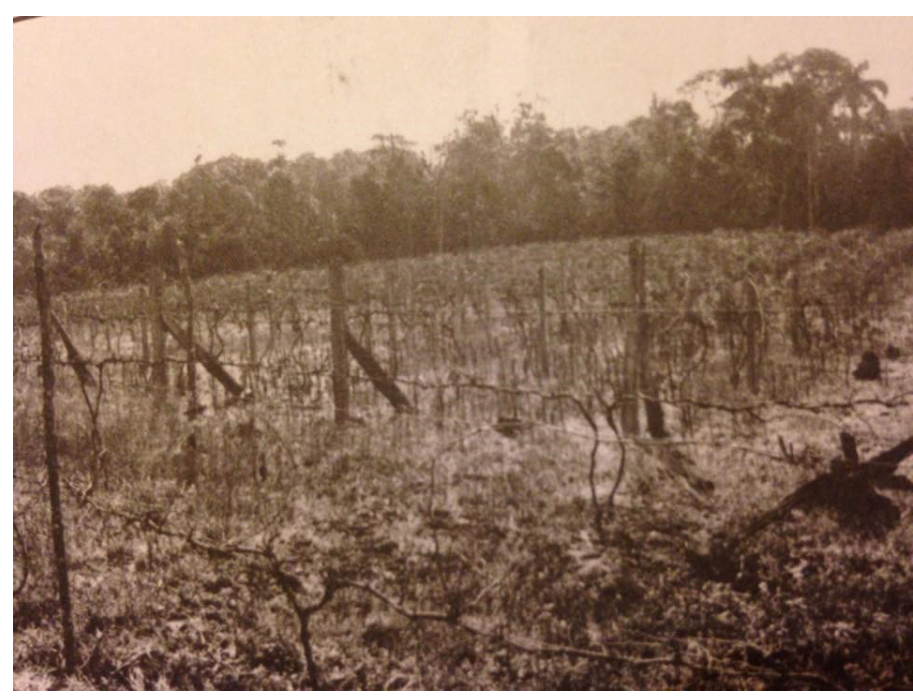

Parreiral da Colônia Cecília. Fonte: Bach, 2011.

Cecília Colony's vineyard. Source: Bach, 2011. 

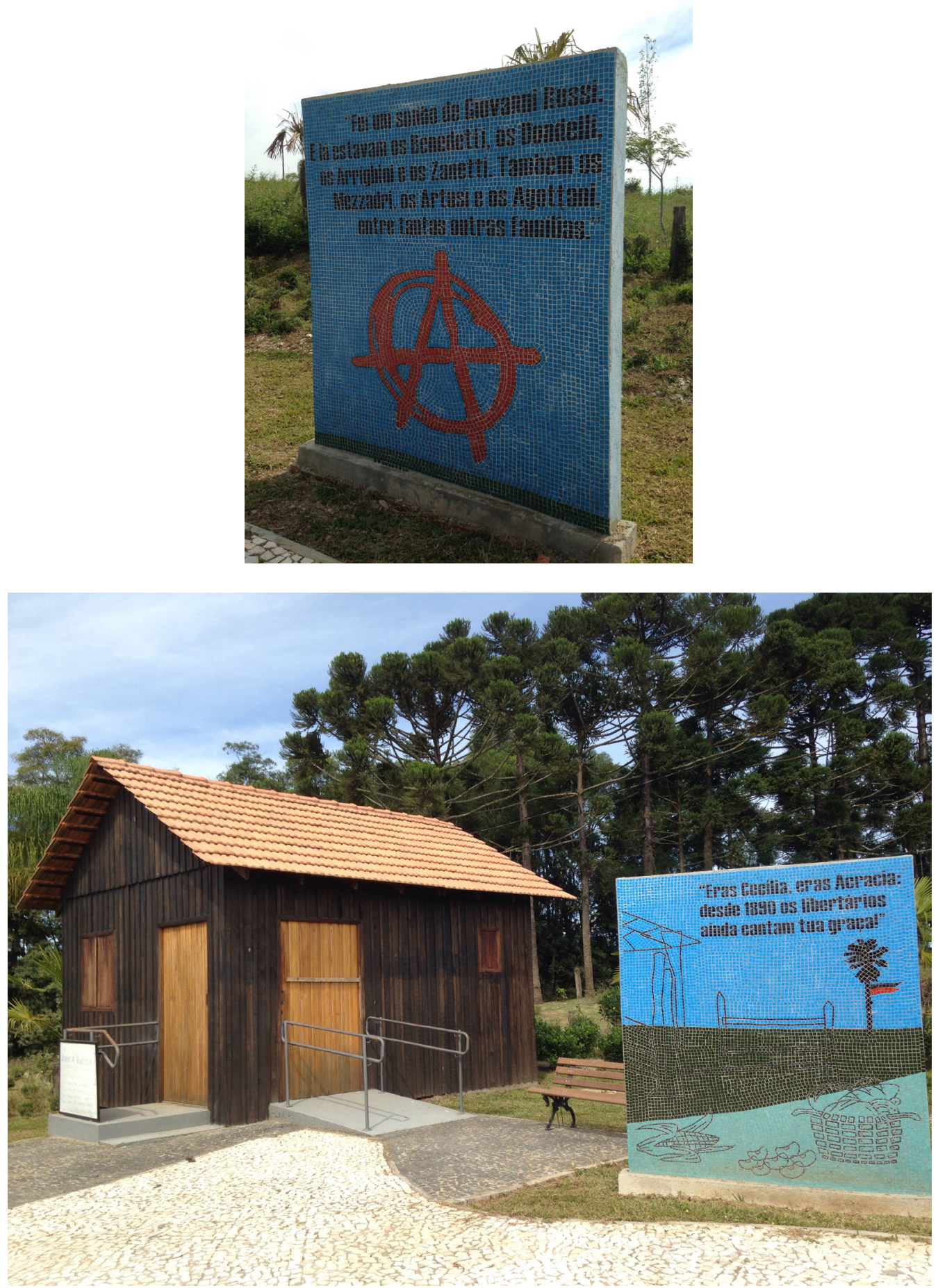

Fotos do Memorial da Colônia Cecília. Fonte: Dados da pesquisa, 2015.

Cecília Colony Memorial photos. Source: Research data, 2015. 


\begin{tabular}{|c|c|c|c|}
\hline Produtor & $\begin{array}{c}\text { Tamanho da produção } \\
\text { (garrafas) }\end{array}$ & Infraestrutura turística & $\begin{array}{c}\text { Interesse em investir } \\
\text { em turismo }\end{array}$ \\
\hline 1 & $\begin{array}{c}400 \text { garrafas de vinho e } \\
600 \text { de suco/ano }\end{array}$ & $\begin{array}{l}\text { Possui estacionamento, espaço } \\
\text { para venda de produtos e área } \\
\text { para alimentação com banheiros }\end{array}$ & $\begin{array}{c}\text { Possui interesse. } \\
\text { Está investindo } \\
\text { em café colonial, } \\
\text { almoço, quiosque e } \\
\text { entretenimento para o } \\
\text { visitante }\end{array}$ \\
\hline 2 & $\begin{array}{c}2 \text { mil garrafas de } \\
\text { vinhos e } 500 \text { de suco/ } \\
\text { ano }\end{array}$ & $\begin{array}{l}\text { Possui espaço para venda de } \\
\text { produtos }\end{array}$ & $\begin{array}{l}\text { Possui interesse, vende } \\
\text { seus produtos em casa }\end{array}$ \\
\hline 3 & $\begin{array}{c}4 \text { mil garrafas de vinho } \\
\text { e } 1500 \text { de suco/ano }\end{array}$ & $\begin{array}{l}\text { Possui espaço para venda de } \\
\text { produtos }\end{array}$ & $\begin{array}{l}\text { Não possui interesse. } \\
\text { Vende seus produtos } \\
\text { em mercados e em casa }\end{array}$ \\
\hline 4 & \begin{tabular}{|c|}
5 mil garrafas de vinho \\
e 1500 de suco/ano
\end{tabular} & $\begin{array}{l}\text { Possui espaço para venda de } \\
\text { produtos } \\
\end{array}$ & Não possui interesse \\
\hline 5 & $\begin{array}{c}10 \text { mil garrafas de } \\
\text { vinhos e sucos/ano }\end{array}$ & $\begin{array}{c}\text { Possui espaço para venda de } \\
\text { produtos }\end{array}$ & Não possui interesse \\
\hline 6 & $\begin{array}{c}10 \text { a } 15 \text { mil garrafas de } \\
\text { vinho e } 5 \text { mil de suco } \\
\text { de uva/ano }\end{array}$ & $\begin{array}{l}\text { Possui espaço para venda de } \\
\text { produtos }\end{array}$ & $\begin{array}{l}\text { Atendem o público na } \\
\text { época da colheita, com } \\
\text { o sistema colha e pague }\end{array}$ \\
\hline 7 & \begin{tabular}{|c|}
$\begin{array}{c}10 \text { a } 15 \text { mil garrafas de } \\
\text { vinho e } 5 \text { mil de suco } \\
\text { de uva/ano }\end{array}$ \\
\end{tabular} & $\begin{array}{l}\text { Possui espaço para venda de } \\
\text { produtos }\end{array}$ & $\begin{array}{l}\text { Atendem o público na } \\
\text { época da colheita, com } \\
\text { o sistema colha e pague }\end{array}$ \\
\hline 8 & \begin{tabular}{|c|}
$\begin{array}{c}10 \text { a } 15 \text { mil garrafas de } \\
\text { vinho e } 5 \text { mil de suco } \\
\text { de uva/ano }\end{array}$ \\
\end{tabular} & $\begin{array}{l}\text { Possui estacionamento e espaço } \\
\text { para venda de produtos }\end{array}$ & $\begin{array}{c}\text { Está investindo em café } \\
\text { colonial, camping e } \\
\text { pousada }\end{array}$ \\
\hline 9 & $\begin{array}{c}10 \text { mil garrafas de } \\
\text { vinho e } 15 \text { mil de suco/ } \\
\text { ano }\end{array}$ & $\begin{array}{l}\text { Possui espaço para venda de } \\
\text { produtos }\end{array}$ & $\begin{array}{l}\text { Possui interesse, já } \\
\text { tem visitação e vende } \\
\text { seus produtos em } \\
\text { casa, restaurantes e } \\
\text { mercados }\end{array}$ \\
\hline 10 & $\begin{array}{l}20 \text { mil garrafas de } \\
\text { vinhos e sucos/ano }\end{array}$ & $\begin{array}{l}\text { Possui espaço para venda de } \\
\text { produtos }\end{array}$ & $\begin{array}{l}\text { Não possui interesse. } \\
\text { Vende seus produtos } \\
\text { em mercados, } \\
\text { restaurantes e feiras }\end{array}$ \\
\hline
\end{tabular}

Resultado das pesquisas com os produtores. Fonte: Dados da pesquisa, 2015. 
Vol. 1 - n. 2 - 2016

\begin{tabular}{|c|c|c|c|}
\hline Producer & $\begin{array}{c}\text { Production capability } \\
\text { (bottles) }\end{array}$ & Touristic infraestructure & $\begin{array}{c}\text { Interest on investing in } \\
\text { tourism }\end{array}$ \\
\hline 1 & $\begin{array}{c}400 \text { wine bottles and } \\
600 \text { juice bottles a year }\end{array}$ & $\begin{array}{l}\text { Has parking lot, selling and eating } \\
\text { spaces with bathrooms. }\end{array}$ & $\begin{array}{c}\text { Interested. Has been } \\
\text { investing on colonial } \\
\text { café and lunch, kiosk, } \\
\text { entertainment for the } \\
\text { visitors. }\end{array}$ \\
\hline 2 & $\begin{array}{l}2 \text { thousand wine bottles } \\
500 \text { juice bottles/year }\end{array}$ & Has space for goods selling. & $\begin{array}{c}\text { Interested and already } \\
\text { sells at home }\end{array}$ \\
\hline 3 & $\begin{array}{c}4 \text { thousand wine bottles } \\
\text { and } 1500 \text { juice bottles } \\
\text { /year }\end{array}$ & Has space for goods selling. & $\begin{array}{c}\text { Not interested. Sells his } \\
\text { products in markets and } \\
\text { at home }\end{array}$ \\
\hline 4 & $\begin{array}{c}5 \text { thousand wine bottles } \\
\text { and } 1500 \text { juice bottles } \\
\text { /year }\end{array}$ & Has space for goods selling. & Not Interested \\
\hline 5 & $\begin{array}{c}10 \text { thousand wine and } \\
\text { juice bottles / year }\end{array}$ & Has space for goods selling. & Not interested \\
\hline 6 & $\begin{array}{l}10 \text { a } 15 \text { thousand wine } \\
\text { bottles and } 5 \text { thousand } \\
\text { juice bottles and /year }\end{array}$ & Has space for goods selling. & $\begin{array}{c}\text { Attends the public at } \\
\text { harvest team, with } \\
\text { the 'harvest and pay' } \\
\text { system }\end{array}$ \\
\hline 7 & $\begin{array}{l}10 \text { a } 15 \text { thousand wine } \\
\text { bottles and } 5 \text { thousand } \\
\text { juice bottles and /year }\end{array}$ & Has space for goods selling. & $\begin{array}{c}\text { Attends the public at } \\
\text { harvest team, with } \\
\text { the 'harvest and pay' } \\
\text { system }\end{array}$ \\
\hline 8 & $\begin{array}{l}10 \text { a } 15 \text { thousand wine } \\
\text { bottles and } 5 \text { thousand } \\
\text { juice bottles and /year }\end{array}$ & $\begin{array}{l}\text { Has parking lot and space for } \\
\text { goods selling. }\end{array}$ & $\begin{array}{c}\text { Currently investing on } \\
\text { colonial café, camping } \\
\text { and inn. }\end{array}$ \\
\hline 9 & $\begin{array}{c}10 \text { thousand wine } \\
\text { bottles and } 15 \\
\text { thousand juice bottles } \\
\text { /year }\end{array}$ & Has space for goods selling. & $\begin{array}{c}\text { Interested. Already } \\
\text { has visits and sells his } \\
\text { products at restaurants, } \\
\text { markets and at home. }\end{array}$ \\
\hline 10 & $\begin{array}{l}20 \text { thousand wine and } \\
\text { juice bottles /year }\end{array}$ & Has space for goods selling. & $\begin{array}{l}\text { Not interested. Sells his } \\
\text { products in markets, } \\
\text { restaurants and fairs }\end{array}$ \\
\hline
\end{tabular}

Research with the producers results. Source: Research data, 2015. 


\begin{tabular}{|c|c|c|c|c|c|c|c|c|c|c|}
\hline \multirow{2}{*}{ Atividade } & \multicolumn{10}{|c|}{ Existência da atividade na propriedade } \\
\hline & 1 & 2 & 3 & 4 & 5 & 6 & 7 & 8 & 9 & 10 \\
\hline $\begin{array}{l}\text { Material Promocional (Folders; } \\
\text { Flyers; Sites; Páginas em Redes } \\
\text { Sociais, etc.) }\end{array}$ & $\mathrm{x}$ & & & & & & & & & \\
\hline Mapas & & & & & & & & & & \\
\hline Sinalização & & & & & & & & & & \\
\hline $\begin{array}{l}\text { Visitação à propriedade e explicação } \\
\text { do processo de produção }\end{array}$ & $\mathrm{x}$ & $\mathrm{X}$ & $\mathrm{x}$ & $\mathrm{x}$ & $\mathrm{X}$ & $\mathrm{x}$ & $\mathrm{x}$ & $x$ & $\mathrm{X}$ & $\mathrm{x}$ \\
\hline Sistema "colha e pague" & $\mathrm{X}$ & & & $\mathrm{X}$ & & $\mathrm{x}$ & $\mathrm{x}$ & & $\mathrm{x}$ & $\mathrm{x}$ \\
\hline Participação na produção & & & & & & & & & & \\
\hline Degustação dos vinhos & $\mathrm{x}$ & & & $\mathrm{x}$ & $\mathrm{X}$ & & & $x$ & & $\mathrm{x}$ \\
\hline $\begin{array}{l}\text { Cursos e Palestras (Ex: Sobre vinhos; } \\
\text { harmonização; serviço, etc.) }\end{array}$ & & & & & & & & & & \\
\hline \begin{tabular}{|l|l|} 
Eventos (Gastronômicos, Sociais, \\
Culturais, Pedagógicos, etc.)
\end{tabular} & & & & & & & & & & \\
\hline Possibilidade de pernoite no local & & & & & & & & & & \\
\hline Espaço para venda de produtos & $\mathrm{X}$ & $\mathrm{x}$ & $\mathrm{X}$ & $\mathrm{x}$ & $\mathrm{X}$ & $\mathrm{X}$ & $\mathrm{x}$ & $\mathrm{x}$ & $\mathrm{x}$ & $\mathrm{x}$ \\
\hline $\begin{array}{l}\text { Pós-visita: Pesquisa de satisfação/ } \\
\text { Banco de dados dos visitantes }\end{array}$ & & & & & & & & & & \\
\hline $\begin{array}{l}\text { Museu ou Espaço de } \\
\text { relacionado ao vinho }\end{array}$ & & & & & & & & & & \\
\hline
\end{tabular}

Atividades das propriedades vitivinícolas de Palmeira. Fonte: Dados da pesquisa, 2015.

\begin{tabular}{|c|c|c|c|c|c|c|c|c|c|c|}
\hline \multirow{2}{*}{ Activity } & \multicolumn{10}{|c|}{ Occurrance on the property } \\
\hline & 1 & 2 & 3 & 4 & 5 & 6 & 7 & 8 & 9 & 10 \\
\hline $\begin{array}{l}\text { Promotional Material (Folders, Flyers, } \\
\text { sites, pages in social networks, etc.) }\end{array}$ & $x$ & & & & & & & & & \\
\hline Maps & & & & & & & & & & \\
\hline Sinalizing & & & & & & & & & & \\
\hline $\begin{array}{l}\text { Visitation to the property and } \\
\text { explanation of the production process }\end{array}$ & $X$ & $X$ & $x$ & $x$ & $X$ & $\mathrm{x}$ & $x$ & $x$ & $\mathrm{x}$ & $\mathrm{x}$ \\
\hline Sistem "harvest and pay" & $\mathrm{x}$ & & & $x$ & & $x$ & $X$ & & $X$ & $x$ \\
\hline Participation on producing. & & & & & & & & & & \\
\hline Wine tasting & $X$ & & & $x$ & $x$ & & & $x$ & & $x$ \\
\hline \begin{tabular}{|lll} 
Courses (Ex: About wines; \\
harmonization, service, etc.)
\end{tabular} & & & & & & & & & & \\
\hline $\begin{array}{l}\text { Events (Gastronomic, social, cultural, } \\
\text { pedagogical, etc.) }\end{array}$ & & & & & & & & & & \\
\hline Overnight possibility on site & & & & & & & & & & \\
\hline Selling space for products & $\mathrm{x}$ & $x$ & $x$ & $x$ & $\mathrm{x}$ & $\mathrm{x}$ & $x$ & $x$ & $\mathrm{x}$ & $x$ \\
\hline \begin{tabular}{|l|} 
After visit: Satisfaction survey \\
Visitor Database
\end{tabular} & & & & & & & & & & \\
\hline $\begin{array}{l}\text { Memory Space or Museum related to } \\
\text { wine }\end{array}$ & & & & & & & & & & \\
\hline
\end{tabular}

